\title{
Thai Non-Life Insurance Companies' Resilience and the Historic 2011 Floods: Some Recommendations for Greater Sustainability
}

\author{
Kanitsorn Terdpaopong ${ }^{1, *}$ and Robert C. Rickards ${ }^{2}$ \\ 1 Faculty of Accountancy, Rangsit University, Pathumthani 12000, Thailand \\ 2 Department of Business Administration-Public Management, German Police University, \\ 48165 Münster, Germany; rrickards@hs-harz.de \\ * Correspondence: kanitsorn@rsu.ac.th; Tel.: +66-81-809-5085
}

Citation: Terdpaopong, K.; Rickards, R.C. Thai Non-Life Insurance Companies' Resilience and the Historic 2011 Floods: Some Recommendations for Greater Sustainability. Sustainability 2021, 13, 8890. https://doi.org/10.3390/ su13168890

Academic Editor: João Carlos de Oliveira Matias

Received: 7 May 2021

Accepted: 5 August 2021

Published: 9 August 2021

Publisher's Note: MDPI stays neutral with regard to jurisdictional claims in published maps and institutional affiliations.

Copyright: (c) 2021 by the authors. Licensee MDPI, Basel, Switzerland. This article is an open access article distributed under the terms and conditions of the Creative Commons Attribution (CC BY) license (https:// creativecommons.org/licenses/by/ $4.0 /)$.

\begin{abstract}
The severe flooding occurring in parts of Thailand in 2011 constituted the fifth most costly catastrophe worldwide during the past 31 years. Many businesses suffered either directly or indirectly. A sharp downturn in the country's economy resulted, with Thai non-life insurance companies' annual losses totaling USD $4.1 \mathrm{bn}$. Focusing first on changes in their key performance indicators (KPIs) as evidence of their financial resilience, this study analyses data for 58 companies from 2008-2010 (years prior to the flooding), 2011 (the flood year), and 2012-2014 (the immediate post-flood years). Descriptive and inferential statistics depict differences in firm characteristics and key performance indicators between these periods. The findings show that: (1) not surprisingly, the floods had a major impact on Thai non-life insurance companies' finances; and (2) even after two years, they still had not recovered fully. Then, employing Data Envelopment Analysis (DEA), the study assesses the relative efficiency of 58 Thai non-life insurance companies in using their assets to generate operating profit. The evidence indicates that: (1) larger insurance companies are more efficient than smaller ones in this regard; and (2) almost all the entities examined performed less efficiently during the post-flood years than in earlier periods. These results serve as the basis for recommendations to Thai non-life insurance companies, government policymakers, and future researchers. Although Thai non-life insurance companies survived the challenges they faced during the study period, implementation of the measures recommended here likely would boost their technical efficiency and financial resilience, thereby facilitating their ability to operate more sustainably in the long run.
\end{abstract}

Keywords: resilience; sustainability; floods; non-life insurance; technical efficiency score

\section{Introduction}

Natural disasters have both direct and indirect effects on businesses, households, infrastructure, and economies. Their direct effects may be either tangible and priceable or intangible and unpriceable. Examples of the former include damage to residences, facilities, and other property, while examples of the latter include fatalities, injuries, and inconvenience. In contrast, indirect effects can refer to losses incurred by companies and individuals outside flooded areas, such as adjustments in production and consumption patterns and evacuees' temporary housing costs. Indirect effects also may include societal disruption, psychological trauma, and weakened trust in public authorities [1].

Floods are among the earth's most common and most destructive natural hazards. They occur frequently, constitute enormous socioeconomic challenges, and demand immediate attention. The logic of risk management suggests countries should invest today to safeguard critical infrastructure and centres of economic activity against future floods and other climate-related losses of great magnitude. Moreover, there is a compelling political logic to do so to generate employment and revive economic growth in disaster-affected areas as soon as possible [2]. 
Insurance can serve as a shock absorber for an economy suffering devastation from such unforeseen natural hazards [3], enabling businesses to continue or restore operations in their aftermath [4]. Several previous studies conducted on flood hazard effects are particularly noteworthy here. First, Bin, Kruse and Landry [5] examined flood hazard's impact on coastal property values using the hedonic property pricing technique. They analyzed Geographic Information System data from Carteret County, North Carolina, on National Flood Insurance Program flood zones and residential property transactions. Not surprisingly, the investigators found that location within a flood zone decreases a property's value. Importantly, though, they also found that the price differentials for flood risk and the capitalised value of flood insurance premiums are nearly identical. The flood zone designation and insurance prices thus convey crucial risk information to prospective coastal home buyers [5].

Second, Botzen and Van Den Bergh [6] studied insurance against climate change and flooding in the Netherlands. They found that climate change causes significant economic losses and consequently affects both the insurance industry and public compensation schemes. This research is particularly remarkable, given the country's extraordinary vulnerability to natural catastrophes. The investigation also considers how private insurance policies might be modified to cover increased flood risks, given that such policies currently are not available in the Netherlands. Yet, it seems that when insurance companies do assume some of the risks connected with climate change, social welfare improves [6,7].

Third, Grmanová and Strunz [8] examined 15 commercial insurance companies in Slovakia from 2013 through 2015 using data envelopment analysis (DEA) to generate technical efficiency scores, a Tobit regression model, and the Mann-Whitney U-test. Their research involved forming two groups of insurance companies: one with a return of on assets (ROA) above $2 \%$ and a second with an ROA below $2 \%$. They demonstrated that the technical efficiency scores of the group of insurance companies with an ROA greater than 2 indeed were higher than the second group's scores [8].

Taken together, the abovementioned studies, undertaken in the United States and the Netherlands, emphasize how insurance can cushion the economic and social impacts of flooding, other natural catastrophes, and climate change. Having demonstrated that, the Slovakian research shows a novel way to evaluate insurance companies' efficiency in doing so. Both results are helpful for the present study.

As their US and Dutch counterparts have done and continue to do, Thai non-life insurance companies exercised a buffering function in the wake of heavy flooding during the autumn of 2011. Most losses occurred in the manufacturing sector, when water inundated seven major industrial estates, disrupting supply chains for automobile production and causing a global shortage of hard disk drives lasting throughout 2012 [9]. Thailand's flood losses made it the fifth costliest insured loss event in the past 31 years worldwide [10].

While playing a crucial role in mitigating the damages, in 2011 the Thai non-life insurance industry experienced staggering losses from colossal claims due to business interruption and contingent business interruption (CBI). Moreover, it had provided flood coverage in Thailand without additional premium charges under industrial all risk (IAR) policies [11]. Unlike countries such as Japan, Thai 'fire insurance' also covered flood risks for bigger businesses [11]. On the other hand, approximately $1 \%$ of homeowners and small businesses in Thailand had purchased flood insurance. Consequently, the claims received came mainly from the abovementioned manufacturers. Thus, although the total estimated losses in Thailand were approximately USD $46.5 \mathrm{bn}$. [2], the total estimated insured losses were much lower, but they still amounted to the breathtaking sum of USD $10.8 \mathrm{bn}$. [12].

Nevertheless, by paying claims the insurance industry demonstrated its considerable importance in sustaining the country's economy. It therefore makes sense to examine the non-life insurance companies' health before, during, and after the disaster. How did the 2011 flooding affect the Thai non-life insurance industry? What lessons are there to learn from its experience? The analysis of 58 non-life insurance companies undertaken here suggests answers to these questions. By reducing their customers' business and personal 
risk, financially strong insurance companies help build individual, societal, and economic resilience. Hence, this study should interest government policymakers, business managers, and scholars.

In many countries, there is considerable room for expansion of the insurance market. Indeed, an OECD report shows both the life and the non-life insurance industries are growing, as evidenced by increased written premiums. One can explain these increases either by higher sales of new or existing insurance products, or by higher rates charged on policies currently in force, or by some combination of the two. Additionally, economic growth can spark higher demand for insurance products and thus higher prices for them as well. Conversely, greater competition in the insurance marketplace [13], development of the banking system, and appropriate legal requirements, together with more accurate insurance pricing based on new data analytic techniques, and reduced expenses resulting from use of modern technologies [14] can lead to improvements in the productivity and declines in insurance premiums.

One usually divides the global insurance market into two segments: life insurance and non-life insurance. In 2014, the proportional mix between the two categories in the United States was 42\%:58\%, while in Australia, it was 57\%:43\% [15]. Life insurance was a bigger component of the mix in Thailand, with the respective proportions being approximately $70 \%: 30 \%$. These proportions in the Thai mix of life and non-life insurance remained quite stable throughout the study period [16].

In 2016, the United States accounted for 43.5\% (USD $2.7 \mathrm{tn}$.) of the global non-life insurance market's value (USD 5.0 tn.) [9]. Europe had the second largest share, 33.1\%, of which $6.7 \%$ was in Germany and 5.5\% was in the United Kingdom. The Asia-Pacific region comprised a $20.1 \%$ share of the world market, where Japan and China ranked numbers one and two, respectively, in terms of size in this region. Compared with the non-life insurance market's worldwide value of USD $4.9 \mathrm{tn}$., the Thai market's value of USD $15.6 \mathrm{bn}$. (or $0.3 \%$ ) is tiny. Nonetheless, it is vitally important to Thailand's well-being.

In 2008, the Thai insurance industry comprised 91 companies. During the study period, there was some consolidation, resulting in a decline in the number to 86 . Of the 86,58 were non-life insurance companies that sold home, car and motorcycle, business continuity, fire, marine, and logistics insurance, but not life or health insurance. Among these non-life insurers, five were subsidiaries of foreign headquartered companies. Fiftytwo non-life insurers had listings on the Stock Exchange of Thailand, while the other six were registered as limited companies. Thus, listed companies, whose share ownership was largely private, dominated the Thai non-life insurance market from 2008 through 2014 and continue to do so today [16].

The Thai insurance industry's total direct premium income of USD 106.3 mil. in 2008 grew $31.9 \%$ over the next three years to USD 140.2 mil. in 2011 . Following the heavy flooding in 2011, the direct premium income jumped dramatically to USD 179.5 mil. in 2012, an annual increase of 39.3\% [16]. Thereafter, direct premiums increased more gradually, reaching USD 218.4 mil. in 2017. The increased direct premium income following the 2011 flood likely resulted in customers' heightened awareness of the potential losses arising from natural catastrophes and their desire to transfer that risk to the insurance industry. In addition, the Thai government tried to stimulate the country's post-flood economy utilizing a 'First Car Buyer Scheme.' Beginning in 2012, first-time car buyers received a tax refund of THB 100,000 (or USD 3300 per unit) [16]. Because Type 1 car insurance (first-class car insurance) is compulsory for new cars in Thailand, this popular measure indirectly boosted Thai non-life insurance companies' direct premium income.

\section{Materials and Methods}

\subsection{Materials}

The analysis in the first part of this study relies on 9 widely used KPIs and 2 nonfinancial variables, namely company age and size. The KPIs and variables come from 1 or more of the following 3 sources. The first source is the DuPont model, which analyses an 
entity's return on its equity by examining its profit margin, asset turnover, and financial leverage [17]. Empirical investigations published in scholarly literature during the last ten years comprise the second source. The third source is the Thai regulatory authority that governs non-life insurance, the Office of Insurance Commission. It discloses financial information and key performance indicators regarding the Thai non-life insurance companies on monthly, quarterly, and annual bases [16]. Table 1 lists all 11 variables and their operational definitions.

Table 1. Study Variables and Their Definitions.

\begin{tabular}{|c|c|}
\hline Variables & Definition \\
\hline \multicolumn{2}{|l|}{ KPIs: } \\
\hline $\begin{array}{l}\text { IAPL: Investment-assets-to-policy liabilities } \\
\text { ratio }\end{array}$ & $\begin{array}{l}\text { Total investment assets divided by total policy } \\
\text { liabilities }\end{array}$ \\
\hline LR: Loss ratio & $\begin{array}{l}\text { Net claims expense as a percentage of net } \\
\text { written premium revenue }\end{array}$ \\
\hline OER: Operating expense ratio & $\begin{array}{l}\text { Operating expenses (including commission, } \\
\text { brokerage, underwriting and other operating } \\
\text { expenses) as a percentage of net written } \\
\text { premium revenue }\end{array}$ \\
\hline CBR: Combined ratio & $\begin{array}{l}\text { Sum of the loss ratio (LR) and the operating } \\
\text { expense ratio (OER) }\end{array}$ \\
\hline ROA: Return on assets & $\begin{array}{l}\text { Operating profit before taxes and interest } \\
\text { (EBIT) divided by average total assets }\end{array}$ \\
\hline ROE: Return on equity & Net profit divided by average equity \\
\hline OPM: Operating profit margin & $\begin{array}{l}\text { Operating profit divided by net written } \\
\text { premiums }\end{array}$ \\
\hline NPM: Net profit margin & $\begin{array}{l}\text { Insurance profit divided by net written } \\
\text { premium revenue }\end{array}$ \\
\hline DE: Debt-to-equity ratio & Total liabilities divided by total equity \\
\hline
\end{tabular}

\begin{tabular}{ll}
\hline Size & $\begin{array}{l}\text { Natural logarithm of the amount of net written } \\
\text { premium revenue }\end{array}$ \\
\hline Age & Number of years in operation \\
\hline $\begin{array}{l}\text { Adapted from Office of Insurance Commission, website: } \\
\text { Tabltp compiled by the authors. }\end{array}$
\end{tabular}

Four KPIs commonly used to measure profitability are: return on assets (ROA), return on equity (ROE), operating profit margin ratio, and net profit margin ratio. The profitability and liquidity of Thai non-life insurance companies were important concerns during the 2011 flooding due to the large claims they had to pay and subsequent new, more expansive conditions for purchasing reinsurance. Such adverse conditions normally lead to consolidation in an industry as weakened companies seek to liquidate assets and/or merge with stronger firms in order to survive and grow their business.

The return on assets (ROA) is a financial ratio many researchers employ to assess how well management uses a company's total resources to generate earnings [18-27]. Return on equity (ROE), which measures profit earned with the money shareholders have invested, is a similar measure [18,19,21-25,28-31].

Both the operating profit margin (OPM) and net profit margin (NPM) are relative indicators of how much profit a company makes after paying for its costs. The OPM measures that difference before taxation and interest expenses, while the NPM does so after taxation and interest expenses. The two ratios are expressed as a percentage of sales, and thus, also reflect a company's success in controlling the costs and expenses associated with its business operations [18,22,25,29,30,32,33]. 
Considering the many claims in the flood year, all 4 profitability indicators should have declined and then improved gradually during the subsequent period. Hence, the first null hypothesis:

Hypothesis 1 (H1). The profitability of Thai non-life insurance companies was unchanged during the study period (2008-2014).

In addition, 3 performance ratios indicate how efficiently management utilises its assets and equity relative to a company's costs. The ratio of investment assets to policy liabilities (IAPL) shows the amount of the former produced with help from the latter $[18,19,22,28,34,35]$. It also makes use of the losses-incurred-to-earned-premiumswritten ratio to reveal periods with unexpectedly high claim payments relative to income earned from policyholders $[18,19,22,28,34,35]$.

The loss ratio (LR) represents total losses incurred (both paid and reserved) in claims minus premiums paid to reinsurance companies) plus adjustment expenses divided by the total premiums earned. It indicates whether a company is collecting more premiums than the amount it pays out in claims. A company with high loss claims may experience financial difficulties $[18,19,25,26,28,30,34-36]$.

Put simply, the combined ratio (CBR) is calculated by taking incurred losses plus operating expenses and dividing them by earned premiums. This ratio is a quick, simple, and widely used indicator of an insurance company's financial health $[20,25,26,30]$.

Given their popularity among researchers and the availability of appropriate data, this study has adopted these 3 ratios to discover whether the cost efficiency of non-life insurance companies' financial performance dropped during the flood year and recovered afterwards. Hence, the second null hypothesis is:

Hypothesis 2 (H2). The cost efficiency performance of Thai non-life insurance companies was unchanged during the study period (2008-2014).

Typically, insurance companies maintain their liquidity at a level that allows them to pay their liabilities. The sudden occurrence of huge claims, however, can pose a serious challenge for them. That is true even if they already have reinsured most of the losses and thus have transferred most of the associated risks to reinsurers. Although they ultimately will bear only a minor portion of the losses, the general practice is for insurance companies initially to pay policyholders' claims and to recover those payments from the reinsurers at a later date. Therefore, despite transferring most of the risks associated with flood damages to reinsurers, a non-life insurance company potentially may face a liquidity crisis when it suddenly receives a large number of claims. In response, management must increase the company's liquidity either through large-scale borrowing or soliciting additional shareholder equity.

The debt-to-equity (DE) ratio is a key financial performance indicator frequently used to measure a company's leverage. The acceptable DE ratio level varies according to multiple factors including profitability, cash flow, and capital intensity. The median DE ratio also differs across industries. For example, capital-intensive industries, such as utilities, have relatively high DE ratios, while labour-intensive industries, like most services, have relatively low ones. Generally, ratios of 0.5 and below are considered excellent, while ratios above 2.0, usually are viewed unfavourably. The typical median DE ratio of U.S.-based, publicly-traded insurance companies is between 0.2 and 0.3 .

Studies employing the DE ratio to indicate insurance companies' financial stability have found that the ones with higher DE levels put their liquidity at risk $[18,21-23,25,27,31,34,36]$. Consequently, investors, creditors, and other stakeholders rely on this ratio to analyse how well a given company would be able to fulfill its debt obligations in the event of an insured natural catastrophe or liquidation. Hence, the third null hypothesis is: 
Hypothesis 3 (H3). The debt-to-equity ratio of Thai non-life insurance companies was unchanged during the study period (2008-2014).

Due to their age, older firms are more experienced and have established reputations that allow them to earn a higher margin on sales and thus greater profits [37-43]. However, some researchers argue that older firms are more bureaucratic and therefore less flexible, slower to adapt themselves to shifting market conditions, and less profitable [44]. Hence, the strength and direction of the variable's posited effect here are uncertain and require empirical investigation.

The size of a company's insurance business also affects its financial performance [40,45-49]. Written premiums constitute the main source of an insurance company's revenue and therefore are a good indicator of its size. A larger insurer can exploit economies of scale to become more efficient in using these premiums to earn income compared to a smaller one. Furthermore, regulators are less likely to liquidate large insurers. Therefore, small insurers are more vulnerable to insolvency [49]. Additionally, a small company may find it more difficult to compete on price, name recognition, or the development and introduction of new products. Larger sized firms thus may tend to be technically more efficient than smaller ones. However, large size also may be associated with certain inefficiencies [50]. Numerous scholars have examined the effect of an insurance company's size on its efficiency. Yao et al. [51] evaluated the technical efficiency of 22 insurance businesses in China using the DEA approach. They investigated the hypothesis that large insurers are technically more efficient than small insurers. This argument was based on the fact that, while small insurance businesses offer more affordable services, large insurance businesses are more resistant to bankruptcy. Using a survey of Greek insurance companies, Borges, Nektarios, and Barros [52] similarly found that large, listed life insurance businesses are more efficient. According to Barros, Nektarios, and Assaf [53], though, the variable "large size" has a detrimental effect on efficiency.

Besides written premiums, though, insurance companies generate income through their investments and by holding, using and/or disposing, over a period of time, of other assets (including property, plant and equipment, intangible assets, and property right assets) as well. Total assets, therefore, also ought to affect their efficiency scores.

However, that may be, the efficiency with which Thai non-life insurance companies convert written premiums into operating profit should drop due to losses experienced during the flooding and subsequently recover. Hence, the fourth, fifth, and sixth null hypotheses are:

Hypothesis 4 (H4). There is no statistically significant difference between insurance companies' efficiency score averages during the study's periods (before, during, and after the 2011 floods).

Hypothesis 5 (H5). Thai non-life insurance companies' age does not affect their technical efficiency scores.

Hypothesis 6 (H6). Thai non-life insurance companies' total assets do not affect their technical efficiency scores.

\subsection{Methods}

This study analysed panel data for 58 Thai non-life insurance companies for the period from 2008 through 2014. Thailand's Office of Insurance Commission (OIC) was the primary data source. Analysis of these data involved the application of both descriptive statistics (percentages, means, and standard deviations) and inferential statistics-t-tests for means of independent samples, correlation, data envelopment analysis (DEA) [54,55], and Tobit regression. The first 3 hypotheses were investigated via $t$-tests for both paired and independent samples. Such tests were particularly well-suited to discovering whether variables differed significantly between pre- and post-flood years. Tests of the fourth, fifth, and sixth hypotheses relied on DEA and Tobit regression analyses. They involved 
using DEA to calculate technical efficiency scores as a first step and then in a second step employing a Tobit regression model to discover test variables potentially influencing those scores.

The concept of efficiency developed by Farrell [54] is a relationship between the outputs and the inputs employed in their production. One way to view technical efficiency is to see it as the ability to acquire maximum output from a given set of inputs. Charnes et al. [55] created the DEA approach with constant return to scale (CRS), a widely used mathematical tool for determining technical efficiency in a variety of industries. The envelopment surface varies according to the model's scale assumptions. Generally, twoscale assumptions are in use by researchers: constant returns to scale and variable returns to scale (VRS). The latter category contains both increasing and decreasing scale returns. Conversely, CRS reflects the fact that output fluctuates directly in proportion to changes in inputs. In either case, DEA evaluates the efficiency of each individual entity relative to the maximum efficiency score that can be achieved with a given set of inputs. This method makes no assumptions about the analytical form of the observed inputs and outputs, and thus allows for the use of a variety of measurement metrics. Accordingly, DEA produces relative efficiency metrics, which vary according to the number of entities involved, as well as the number and structure of the input and output variables. The DEA scores presented here were generated by a model that assumes varying returns to scale. That is because insurance company decision makers have considerable control over improving input or output levels. The model also has an output orientation because it elucidates the extent to which operating profit can be increased without increasing input levels.

The second stage of the analysis ascertains factors contributing to the technical efficiency scores. In output-oriented DEA models, these scores have values between 0 and 1 . For this reason, the limited dependent variable regression technique (Hoff, 2007; Osgood, Finken and McMorris, 2002) is used to identify linkages between the scores and relevant model elements. Although some scholars criticise its utilization [56], censored regression models, also known as Tobit regression models, are employed frequently in practical work. By way of comparison, the use of standard linear regression often is inadvisable and may yield badly skewed results when least-squares assumption requirements are not satisfied [8]. The selection of the best performing Tobit model relies on log-likelihood (1l), Akaike's information criteria (AIC) [57] and the Bayesian information criterion (BIC) [58].

\section{Results}

\subsection{Financial Structure of Non-Life Insurance Companies during 2008-2014}

Table 2 describes the structures of the statement of financial position and income statement of the 58 Thai non-life insurance companies across the study period's seven years. The first seven columns report the statement elements taken from the OIC website. The next seven columns list the different financial statement components as common size percentages. That is, it displays all items as percentages of a common base amount (such as total assets on the statement of financial position and premium revenue on the income statement), rather than as absolute numbers. These percentages facilitate comparisons between companies and across time periods.

Table 2. Financial Structure of Non-Life Insurance Companies 2008-2014.

\begin{tabular}{ccccccccccccccc}
\hline & \multicolumn{1}{c}{ Financial Statement Amounts (USD. Mil.) } & \multicolumn{1}{c}{ Common Size (\%) } \\
\hline Year & $\mathbf{2 0 0 8}$ & $\mathbf{2 0 0 9}$ & $\mathbf{2 0 1 0}$ & $\mathbf{2 0 1 1}$ & $\mathbf{2 0 1 2}$ & $\mathbf{2 0 1 3}$ & $\mathbf{2 0 1 4}$ & $\mathbf{2 0 0 8}$ & $\mathbf{2 0 0 9}$ & $\mathbf{2 0 1 0}$ & $\mathbf{2 0 1 1}$ & $\mathbf{2 0 1 2}$ & $\mathbf{2 0 1 3}$ & $\mathbf{2 0 1 4}$ \\
\hline & & \multicolumn{10}{c}{ Statement of Financial Position } \\
\hline $\begin{array}{c}\text { Investment } \\
\text { Assets }\end{array}$ & 2591 & 3385 & 4747 & 5038 & 6366 & 6941 & 8344 & 71.9 & 78.1 & 77.8 & 20.5 & 32.9 & 45.8 & 56.5 \\
\hline $\begin{array}{c}\text { Other } \\
\text { Assets }\end{array}$ & 809 & 754 & 1088 & 19,224 & 12,612 & 7810 & 5914 & 22.5 & 17.4 & 17.8 & 78.1 & 65.1 & 51.5 & 40 \\
\hline
\end{tabular}


Table 2. Cont

\begin{tabular}{|c|c|c|c|c|c|c|c|c|c|c|c|c|c|c|}
\hline \multirow[b]{2}{*}{ Year } & \multicolumn{7}{|c|}{ Financial Statement Amounts (USD. Mil.) } & \multicolumn{7}{|c|}{ Common Size (\%) } \\
\hline & 2008 & 2009 & 2010 & 2011 & 2012 & 2013 & 2014 & 2008 & 2009 & 2010 & 2011 & 2012 & 2013 & 2014 \\
\hline \multicolumn{15}{|c|}{ Statement of Financial Position } \\
\hline $\begin{array}{c}\text { Total } \\
\text { Assets }\end{array}$ & 3605 & 4332 & 6099 & 24,626 & 19,371 & 15,170 & 14,777 & 100 & 100 & 100 & 100 & 100 & 100 & 100 \\
\hline $\begin{array}{c}\text { Policy } \\
\text { Liabilities }\end{array}$ & 1799 & 1934 & 2584 & 20,796 & 12,994 & 7806 & 6558 & 49.9 & 44.6 & 42.4 & 84.5 & 67.1 & 51.5 & 44.4 \\
\hline $\begin{array}{c}\text { Other } \\
\text { Liabilities }\end{array}$ & 709 & 842 & 1431 & 1456 & 2727 & 3225 & 2916 & 19.7 & 19.4 & 23.5 & 5.9 & 14.1 & 21.3 & 19.7 \\
\hline $\begin{array}{c}\text { Total } \\
\text { Liabilities }\end{array}$ & 2508 & 2777 & 4014 & 22,251 & 15,722 & 11,031 & 9474 & 69.6 & 64.1 & 65.8 & 90.4 & 81.2 & 72.7 & 64.1 \\
\hline $\begin{array}{l}\text { Capital } \\
\text { Fund }\end{array}$ & 1097 & 1556 & 2085 & 2375 & 3649 & 4139 & 5303 & 30.4 & 35.9 & 34.2 & 9.6 & 18.8 & 27.3 & 35.9 \\
\hline \multicolumn{15}{|c|}{ Income Statement } \\
\hline $\begin{array}{c}\text { Earned } \\
\text { Premiums }\end{array}$ & 2143 & 2331 & 2842 & 3112 & 3778 & 4483 & 4687 & 100 & 100 & 100 & 100 & 100 & 100 & 100 \\
\hline $\begin{array}{c}\text { Combined } \\
\text { Expenses }\end{array}$ & 2032 & 2235 & 2772 & 7381 & 3593 & 3822 & 4160 & 94.8 & 95.9 & 97.5 & 237.2 & 95.1 & 85.3 & 88.8 \\
\hline $\begin{array}{l}\text { Underwritin } \\
\text { Profit } \\
\text { (Loss) }\end{array}$ & 111 & 100 & 70 & -4270 & 186 & 661 & 527 & 5.2 & 4.3 & 2.5 & -37.2 & 4.9 & 14.8 & 11.2 \\
\hline $\begin{array}{c}\text { Profit } \\
\text { (Loss) from } \\
\text { Operation }\end{array}$ & 242 & 227 & 259 & -4045 & 355 & 867 & 811 & 11.3 & 9.8 & 9.1 & -30 & 9.4 & 19.3 & 17.3 \\
\hline $\begin{array}{l}\text { Net Profit } \\
\text { (Loss) }\end{array}$ & 85 & 163 & 211 & -4094 & 473 & 734 & 705 & 4 & 7 & 7.4 & -31.6 & 12.5 & 16.4 & 15 \\
\hline
\end{tabular}

Source: Office of Insurance Commission, website: http:/ / www.oic.or.th/en (accessed on 15 February 2019). Table compiled by the authors.

In terms of the overall financial structure, the value of Thai non-life insurance companies' assets generally is rather small. Be that as it may, their total assets nearly doubled from USD $3.6 \mathrm{bn}$. in 2008 to USD $6.1 \mathrm{bn}$. in 2010. Then, these assets quadrupled from USD $6.1 \mathrm{bn}$. in 2010 to USD $24.6 \mathrm{bn}$. in 2011, with most of the growth in the category "other assets." In parallel, the non-life insurance companies' total liabilities also increased dramatically, almost doubling from USD $2.5 \mathrm{bn}$. in 2008 to $4.0 \mathrm{bn}$. in 2010, before increasing more than five times to USD $22.3 \mathrm{bn}$. in 2011! The proportion of liabilities compared to total assets was $69.6 \%$ in 2008 , grew to $90.4 \%$ in 2011 , and thereafter declined continuously to $81.2 \%$ in 2012, 72.7\% in 2013 and $64.1 \%$ in 2014, respectively. Combined expenses increased by $166.3 \%$ in 2011 when compared to 2010 . As a result of these increased costs, non-life insurance companies' net profit of USD 259 mil. in 2011 dropped to a loss of USD $4.1 \mathrm{bn}$. in 2011. For the years 2012-2014, the non-life insurance companies again reported net profits because their combined expenses had returned to more normal levels. It is noteworthy that in 2011 the proportion of investment assets dropped dramatically to only $20.5 \%$ of total assets, while policy liabilities became the largest source of the firms' financing $(84.5 \%$ of total assets). Moreover, the ratio of total liabilities to total assets was higher (90.4\%) in 2011 than in any other year during the study period.

Table 3 shows, as one might expect, that the values of the non-life companies' KPIs deteriorated during the flood period. For example, the ratio of investment assets to policy liabilities ratio (IAPL) fell sharply in 2011, but gradually recovered during the immediate post-flood years, although its level in 2014 still was well below that of 2010.

Likewise, both the loss ratio (LR) and the combined expense ratio (CBR) worsened. For each of them, the lower the ratio, the more profitable the insurance company and vice 
versa. If either ratio is above 1 , or $100 \%$, the insurance company is unprofitable and may be in poor financial health because it is paying out more in claims and/or expenses than it is receiving in premiums and/or other income. Both these ratios peaked in 2011, then fell below pre-flood levels over the years from 2012 to 2014.

Table 3. Statistics Describing Thai Non-Life Insurance Companies' KPIs, Age, and Size from 2008 to 2014.

\begin{tabular}{|c|c|c|c|c|c|c|c|c|c|c|c|c|c|c|c|c|}
\hline \multicolumn{2}{|c|}{ Variables } & \multicolumn{3}{|c|}{2008} & \multicolumn{2}{|c|}{2009} & \multicolumn{2}{|c|}{2010} & \multicolumn{2}{|c|}{2011} & \multicolumn{2}{|c|}{2012} & \multicolumn{2}{|c|}{2013} & \multicolumn{2}{|c|}{2014} \\
\hline & & $\mathbf{N}$ & Mean & SDV & Mean & SDV & Mean & SDV & Mean & SDV & Mean & SDV & Mean & SDV & Mean & SDV \\
\hline \multicolumn{17}{|c|}{ Financial Variables: } \\
\hline 1 & IAPL & 58 & 2.76 & 3.13 & 2.95 & 3.29 & 3.2 & 3.95 & 0.68 & 0.82 & 0.89 & 1.23 & 1.17 & 1.35 & 2.27 & 6.44 \\
\hline 2 & LR & 58 & 0.51 & 0.34 & 0.47 & 0.18 & 0.5 & 0.21 & 1.9 & 6.29 & 0.51 & 0.74 & 0.33 & 0.46 & 0.4 & 0.27 \\
\hline 3 & OER & 58 & 0.54 & 0.43 & 0.52 & 0.24 & 1.14 & 1.47 & 2.35 & 6.33 & 0.94 & 0.92 & 0.78 & 0.62 & 0.78 & 0.37 \\
\hline 4 & CBR & 58 & 1.05 & 0.48 & 0.99 & 0.29 & 1.23 & 1.48 & 2.45 & 6.27 & 1.13 & 0.86 & 0.96 & 0.53 & 0.95 & 0.28 \\
\hline 5 & ROA & 58 & 0.02 & 0.11 & 0 & 0.15 & -0.02 & 0.19 & -0.05 & 0.15 & -0.02 & 0.13 & 0.02 & 0.08 & 0.03 & 0.07 \\
\hline 6 & ROE & 58 & -0.06 & 0.48 & -0.07 & 0.73 & 0.03 & 0.62 & -0.54 & 2.82 & -0.24 & 1.02 & 0.08 & 0.38 & 0.04 & 0.43 \\
\hline 7 & OPM & 58 & 0.05 & 0.37 & 0.1 & 0.3 & -0.07 & 1.02 & -1.35 & 6.27 & -0.06 & 0.66 & 0.11 & 0.47 & 0.13 & 0.29 \\
\hline 8 & NPM & 58 & -0.01 & 0.37 & 0.06 & 0.24 & -0.1 & 1.01 & -1.37 & 6.28 & -0.03 & 0.66 & 0.07 & 0.44 & 0.1 & 0.29 \\
\hline 9 & DE & 58 & 2.93 & 2.47 & 2.62 & 3.91 & 2.75 & 2.55 & 11.87 & 25.23 & 8.17 & 10.38 & 4.83 & 7.82 & 3.61 & 4.1 \\
\hline \multicolumn{17}{|c|}{ Characteristic Variables: } \\
\hline 10 & Size * & 58 & 5.73 & 0.66 & 5.64 & 1 & 13.2 & 1.7 & 13.3 & 1.6 & 13.5 & 1.7 & 13.6 & 1.7 & 13.7 & 1.6 \\
\hline 11 & Age ${ }^{* *}$ & 58 & 34.83 & 24.98 & 35.83 & 24.98 & 36.8 & 24.9 & 37.8 & 24.9 & 38.8 & 24.9 & 39.8 & 24.9 & 40.8 & 24.9 \\
\hline
\end{tabular}

The operating profit margin (OPM) and net profit margin (NPM) ratios also display this pattern, but in an inverse fashion. They suffered steep declines in 2011 before rising above their 2010 levels over the 2012-2014 period. Not surprisingly, due to the flood claims, the average return on assets (ROA), already negative in 2010, fell further in 2011, before turning upward in 2012, and becoming positive in 2013 and 2014 after the flood period. The average return on equity (ROE) dropped dramatically in 2011 but turned upward in 2012 as well, and was positive again in 2013 and 2014.

Lastly, the non-life insurance companies' average DE ratio skyrocketed in 2011 to 11.9 from 2.7 in 2010, then declined to 8.2 in 2012, 4.8 in 2013 and 3.6 in 2014. Nevertheless, at the end of the study period it remained above its pre-flood value.

In summary, the non-life insurance companies' average NPM, ROA, and ROE were negative in 2011 and 2012, indicating losses in those years. In 2011, the average LR was greater than 1. In both 2011 and 2012, the average CBR also was greater than 1. Together with the rise in the average DE ratio, these LR and CBR values point to financially unhealthy developments and the need for cash inflows.

Besides changes in their average values, with the exception of ROA, the KPIs' standard deviations in 2011 widened markedly compared to 2010. Although the overall picture for the non-life insurance industry was grim, evidently some companies nevertheless managed to perform better than others. Moreover, by 2013 most of the average KPIs had begun to recover and the standard deviations to narrow, a process that continued through 2014. However, were these observed changes within the overall industry sufficiently large to be statistically significant?

\subsection{Findings for Null Hypotheses 1-3}

The study initially employed paired-sample $t$-tests to examine KPI changes over three different periods: pre-flood (2008, 2009 and 2010); the flood year (2011); and the post-flood 
years $(2012,2013$, and 2014). Table 4 shows that none of the average values for any variable is significantly different year-over-year in the period prior to the flood (i.e., 2008, 2009, and 2010). That means there was little annual change in the Thai non-life insurance companies' financial situation. Then, two KPIs (the ratio of investment assets to policy liabilities (IAPL) and the debt-to-equity ratio (DE), changed significantly from 2010 to 2011 (the flood year). A third KPI (return on assets (ROA) shows a statistically significant change from 2011 to 2012. While these differences also are evident in KPI comparisons for the years 2013 and 2014 with 2011, the other six KPIs display no significant change.

The reason behind this apparent lack of change is that most of the financial effects manifested themselves with a time lag. Given that the flooding occurred in the last quarter of 2011 and considerable delay in estimating losses, filing claims, and processing them resulted due to the destruction and disruption it caused, such a lag is unsurprising. Accordingly, some considerable portion of claims processing likely continued well into the following year. This reasoning suggests that flood and post-flood comparisons would be more meaningful if the former encompassed both 2011 and 2012, while the latter included only 2013 and 2014.

Two tests investigated the mean differences of the nine KPIs between the flood and post-flood periods. Table 5 reports the variables' period means and standard deviations, as well as the test results. Levene's test for the equality of variances showed statistically significant different flood and post-flood values for seven of the nine KPIs. Therefore, the dependent sample $t$-tests for equality of the sample means were conducted on the assumption of unequal variances for seven KPIs and on the assumption of equal variances for the other two KPIs (investment assets to policy liabilities (IAPL) and return on assets (ROA)). These test results indicate statistically significant differences between flood and post-flood values for eight of the nine KPIs, with only the net profit margin (NPM) barely missing the significant difference cutoff.

Summarizing the findings thus far, there are no statistically significant changes in the nine KPIs over the three years prior to the flood. Such change occurs in just three KPIs during the flood year and its immediate aftermath (2011-2012), perhaps due to the flooding occurring rather late in 2011. However, three of the four profitability KPIs are significantly different between the flood and post-flood periods, as are all four of the performance KPIs and the leverage KPI. Accordingly, the first three hypotheses are rejected. Instead, as one might expect, the Thai non-life insurance companies' finances worsened during 2011-2012 and improved during 2013-2014. Yet, even by the end of the study period, their KPIs had not recovered completely their pre-flood levels. 
Table 4. Results from Paired Samples $t$-Tests.

\begin{tabular}{|c|c|c|c|c|c|c|c|c|c|c|c|c|c|c|c|c|c|c|c|c|c|c|}
\hline & \multicolumn{3}{|c|}{ (1) 2008 vs. 2009} & \multicolumn{3}{|c|}{ (2) 2009 vs. 2010} & \multicolumn{4}{|c|}{ (3) 2010 vs. 2011} & \multicolumn{4}{|c|}{ (4) 2011 vs. 2012} & \multicolumn{4}{|c|}{ (5) 2011 vs. 2013} & \multicolumn{4}{|c|}{ (6) 2011 vs. 2014} \\
\hline & \multicolumn{2}{|c|}{$\begin{array}{c}\text { Paired } \\
\text { Differences }\end{array}$} & \multirow[t]{2}{*}{$t$} & \multicolumn{2}{|c|}{$\begin{array}{c}\text { Paired } \\
\text { Differences }\end{array}$} & \multirow[t]{2}{*}{$t$} & \multicolumn{2}{|c|}{$\begin{array}{c}\text { Paired } \\
\text { Differences }\end{array}$} & \multirow[t]{2}{*}{$t$} & & \multicolumn{2}{|c|}{$\begin{array}{c}\text { Paired } \\
\text { Differences }\end{array}$} & \multirow[t]{2}{*}{$t$} & & \multicolumn{2}{|c|}{$\begin{array}{c}\text { Paired } \\
\text { Differences }\end{array}$} & \multirow[t]{2}{*}{$t$} & & \multicolumn{2}{|c|}{$\begin{array}{c}\text { Paired } \\
\text { Differences }\end{array}$} & \multirow[t]{2}{*}{$t$} & \\
\hline & Mean & SDV. & & Mean & SDV. & & Mean & SDV. & & & Mean & SDV. & & & Mean & SDV. & & & Mean & SDV. & & \\
\hline IAPL & -0.19 & 0.97 & -1.45 & -0.27 & 1.47 & -1.39 & 2.53 & 3.88 & 4.96 & $* *$ & -0.21 & 0.63 & -2.61 & $* *$ & -0.49 & 0.80 & -4.65 & $* *$ & -1.59 & 5.85 & -2.08 & * \\
\hline LR & 0.04 & 0.41 & 0.80 & -0.23 & 1.49 & -1.15 & -1.41 & 6.31 & -1.70 & & 1.40 & 6.86 & 1.55 & & 1.57 & 6.67 & 1.79 & $*$ & 1.51 & 6.45 & 1.78 & * \\
\hline OER & 0.02 & 0.25 & 0.55 & -0.17 & 1.58 & -0.82 & -1.20 & 6.48 & -1.41 & & 1.40 & 6.87 & 1.55 & & 1.56 & 6.69 & 1.78 & $*$ & 1.57 & 6.42 & 1.86 & * \\
\hline ROA & 0.03 & 0.10 & 1.85 & 0.00 & 0.06 & 0.51 & 0.03 & 0.17 & 1.16 & & -0.03 & 0.13 & -1.71 & & -0.06 & 0.19 & -2.46 & $*$ & -0.07 & 0.16 & -3.33 & * \\
\hline ROE & 0.01 & 0.55 & 0.15 & -0.01 & 0.81 & -0.05 & 0.57 & 2.88 & 1.51 & & -0.30 & 3.11 & -0.73 & & -0.63 & 2.88 & -1.66 & * & -0.58 & 2.86 & -1.54 & * \\
\hline OPM & -0.04 & 0.41 & -0.79 & 0.35 & 2.49 & 1.06 & 1.28 & 6.41 & 1.52 & & -1.28 & 6.66 & -1.47 & & -1.46 & 6.57 & -1.69 & $*$ & -1.47 & 6.37 & -1.76 & * \\
\hline NPM & -0.07 & 0.41 & -1.31 & 0.34 & 2.50 & 1.04 & 1.28 & 6.40 & 1.52 & & -1.34 & 6.69 & -1.53 & & -1.45 & 6.58 & -1.67 & $*$ & -1.47 & 6.38 & -1.76 & * \\
\hline $\mathrm{DE}$ & 0.31 & 2.97 & 0.79 & -0.22 & 2.87 & -0.57 & -9.13 & 25.14 & -2.77 & $* *$ & 3.70 & 26.53 & 1.06 & & 7.04 & 25.29 & 2.12 & $*$ & 8.27 & 25.47 & 2.47 & * \\
\hline
\end{tabular}


Table 5. Independent Samples $t$-Test of Data from the "Flood Period" and the "Post-Flood Period".

\begin{tabular}{|c|c|c|c|c|c|c|c|c|c|c|c|c|c|c|}
\hline & \multicolumn{3}{|c|}{ Mean } & \multicolumn{6}{|c|}{$\begin{array}{l}\text { Levene's } \\
\text { Test for } \\
\text { Equality of } \\
\text { Variances }\end{array}$} & \multicolumn{5}{|c|}{$t$-Test for Equality of Means } \\
\hline & & \multirow[t]{2}{*}{$\begin{array}{l}\text { Flood } \\
\text { Period }\end{array}$} & \multirow[t]{2}{*}{$\begin{array}{l}\text { Post- } \\
\text { Flood } \\
\text { Period }\end{array}$} & \multirow[t]{2}{*}{$\begin{array}{l}\text { Flood } \\
\text { Period }\end{array}$} & \multirow[t]{2}{*}{$\begin{array}{l}\text { Post- } \\
\text { Flood } \\
\text { Period }\end{array}$} & \multirow[t]{2}{*}{$\mathbf{F}$} & \multirow[t]{2}{*}{ Sig. } & \multirow[t]{2}{*}{$t$} & \multirow[t]{2}{*}{ df } & \multirow[t]{2}{*}{$\begin{array}{l}\text { Sig. (2- } \\
\text { Tailed) }\end{array}$} & \multirow[t]{2}{*}{$\begin{array}{c}\text { Mean } \\
\text { Diff }\end{array}$} & \multirow[t]{2}{*}{$\begin{array}{l}\text { Std. } \\
\text { Error } \\
\text { Diff }\end{array}$} & \multicolumn{2}{|c|}{$\begin{array}{c}95 \% \\
\text { Confidence } \\
\text { Interval of the } \\
\text { Difference }\end{array}$} \\
\hline & & & & & & & & & & & & & Lower & Upper \\
\hline 1 & IAPL & 0.8 & 1.7 & 1 & 4.7 & 2.6 & 0.11 & -2.1 & 230 & $0.04 *$ & -0.9 & 0.4 & -1.8 & -0.1 \\
\hline 2 & LR & 1.2 & 0.4 & 4.5 & 0.4 & 6.6 & $0.01 * *$ & 2 & 116.6 & $0.05 *$ & 0.8 & 0.4 & 0 & 1.7 \\
\hline 3 & OER & 1.6 & 0.8 & 4.6 & 0.5 & 8.4 & $0.00 * *$ & 2 & 117.9 & $0.04 *$ & 0.9 & 0.4 & 0 & 1.7 \\
\hline 4 & CBR & 1.8 & 1 & 4.5 & 0.4 & 7.8 & $0.01 * *$ & 2 & 117 & $0.05^{*}$ & 0.8 & 0.4 & 0 & 1.7 \\
\hline 5 & ROA & 0 & 0 & 0.1 & 0.1 & 2 & 0.16 & -3.4 & 230 & $0.00 * *$ & -0.1 & 0 & -0.1 & 0 \\
\hline 6 & ROE & -0.4 & 0.1 & 2.1 & 0.4 & 8.4 & $0.00 * *$ & -2.3 & 123.5 & $0.03 *$ & -0.5 & 0.2 & -0.9 & -0.1 \\
\hline 7 & OPM & -0.7 & 0.1 & 4.5 & 0.4 & 7.3 & $0.01^{* *}$ & -2 & 116.7 & $0.05 *$ & -0.8 & 0.4 & -1.7 & 0 \\
\hline 8 & NPM & -0.7 & 0.1 & 4.5 & 0.4 & 7.4 & $0.01^{* *}$ & -1.9 & 116.6 & 0.06 & -0.8 & 0.4 & -1.6 & 0 \\
\hline 9 & $\mathrm{DE}$ & 10 & 4.2 & 19.3 & 6.2 & 21.5 & $0.00^{* *}$ & 3.1 & 138.9 & $0.00^{* *}$ & 5.8 & 1.9 & 2.1 & 9.5 \\
\hline
\end{tabular}

\subsection{Findings for Hypotheses 4,5 and 6}

Table 6 reports the matrix of correlations between pairs of the non-life insurance companies' characteristics, namely age and size (as measured by written premiums), the nine financial KPIs, and total assets (TA). There is a weak, but statistically significant, positive correlation between age and size. That is, older companies also are somewhat inclined to be larger and vice versa. Moreover, both older and larger companies tend to have slightly higher returns on their assets (ROAs). However, these two characteristics are not significantly related to any other of the studied KPIs. That is, neither age nor size covaries with eight of the nine KPIs.

Table 6. Pearson Correlation Matrix for Age, Size, Nine Financial KPIs, and Total Assets.

\begin{tabular}{|c|c|c|c|c|c|c|c|c|c|c|c|c|}
\hline & Size & Age & IAPL & LR & OER & CBR & ROA & ROE & OPM & NPM & DE & TA \\
\hline Size & 1 & & & & & & & & & & & \\
\hline Age & $0.200 * *$ & 1 & & & & & & & & & & \\
\hline IAPL & -0.051 & -0.028 & 1 & & & & & & & & & \\
\hline LR & -0.001 & -0.066 & -0.049 & 1 & & & & & & & & \\
\hline OER & -0.048 & -0.094 & -0.019 & $0.961 * *$ & 1 & & & & & & & \\
\hline CBR & -0.034 & -0.086 & -0.040 & $0.966^{* *}$ & $0.987^{* *}$ & 1 & & & & & & \\
\hline ROA & $0.158^{* *}$ & 0.125 * & 0.099 & -0.353 & -0.395 & -0.408 & 1 & & & & & \\
\hline ROE & 0.045 & 0.095 & 0.046 & -0.745 & -0.722 & -0.736 & $0.405^{* *}$ & 1 & & & & \\
\hline OPM & 0.028 & 0.084 & 0.056 & -0.980 & -0.982 & -0.996 & $0.408^{* *}$ & $0.746^{* *}$ & 1 & & & \\
\hline NPM & 0.029 & 0.090 & 0.056 & -0.980 & -0.983 & -0.996 & $0.409 * *$ & 0.746 ** & $0.999 * *$ & 1 & & \\
\hline $\mathrm{DE}$ & -0.081 & -0.085 & -0.142 & 0.039 & 0.019 & 0.023 & -0.037 & -0.322 & -0.029 & -0.028 & 1 & \\
\hline TA & $0.651^{* *}$ & 0.117 & -0.351 & -0.006 & -0.225 & -0.306 & $0.234^{* *}$ & $0.145^{*}$ & $0.238^{* *}$ & -0.029 & $0.242 * *$ & 1.00 \\
\hline $\mathrm{N}$ & 290 & 290 & 290 & 290 & 290 & 290 & 290 & 290 & 290 & 290 & 290 & 290 \\
\hline
\end{tabular}

In contrast, there is a moderately strong, positive relationship between total assets and company size. Additionally, positive, but relatively weak relationships exist between TA and the KPIs ROA, ROE, OPM, and DE.

Among themselves, it is noteworthy that six KPIs (ROE, LR, OER, CBR, OPM and NPM are highly intercorrelated. Yet, variance inflation (VIF) values below 10 indicate the absence of multicollinearity and thus this requisite assumption for employing all the Table 6 variables in a regression analysis of the Thai non-life insurance companies' technical efficiency is met. 
First, though, earned premiums and investment assets were selected as inputs and operating profit as the output in determining technical efficiency scores via DEA. These scores then served as the dependent variable to be explained by age, size, the nine KPIs, and total assets in both traditional linear and Tobit regression models, each with constant returns-to-scale and variable returns-to-scale variants.

Table 7 reports the average technical efficiency scores for each of three total asset classes during the study period. Overall, the scores are highest during the pre-flood years, decline during 2011, and are lowest during the post-flood years. Apparently, company performance generally dropped during the flood year and fell even further in subsequent years. However, entities with more than USD 335 mil. in total assets experienced no statistically significant change in technical efficiency across the periods studied. In contrast, both firms with between USD 170 mil. and USD 335 mil., and those with less than USD 170 mil. in total assets suffered sharp, statistically significant drops in technical efficiency during both the flood and post-flood years. Moreover, during these two periods the average technical efficiency of the 12 companies with the most total assets was markedly higher than that of the 46 companies in the other two total asset classes. Finally, only five of the 58 Thai non-life insurance companies attained the highest possible technical efficiency score of 1 during the pre-flood and flood years, and just three reached that level in the post-flood period. In every instance, though, all were businesses with more than USD 335 mil. in total assets. Clearly, the amount of resources available to a company matters, a finding that is consistent with some previous research [59,60]. Therefore, one can reject both $\mathrm{H} 4$ and H6 because there are substantial differences in the non-life insurance companies' technical efficiency scores and a marked tendency for those scores to vary directly with the amount of an entity's total assets.

Table 7. ANOVA test results on average technical efficiency scores classified by total assets and time periods.

\begin{tabular}{|c|c|c|c|c|c|}
\hline \multirow{2}{*}{\multicolumn{2}{|c|}{ Total Assets }} & \multicolumn{3}{|c|}{ Average Technical Efficiency Score } & \multirow[b]{2}{*}{$\mathbf{F}$} \\
\hline & & \multirow{2}{*}{$\begin{array}{c}\text { Before Flood } \\
0.7440\end{array}$} & \multirow{2}{*}{$\begin{array}{c}\text { During Flood } \\
0.6444\end{array}$} & \multirow{2}{*}{$\begin{array}{c}\text { After Flood } \\
0.5043\end{array}$} & \\
\hline Overall & & & & & 18.511 * \\
\hline >USD 335 mil. & $(n=12)$ & 0.7875 & 0.8133 & 0.7492 & 0.438 \\
\hline & STD & 0.1357 & 0.1707 & 0.1952 & \\
\hline $\begin{array}{l}\text { From USD 170-335 } \\
\text { mil. }\end{array}$ & $(n=12)$ & 0.8067 & 0.7058 & 0.6050 & 4.081 * \\
\hline & STD & 0.1286 & 0.1600 & 0.2181 & \\
\hline <USD 170 mil. & $(n=34)$ & 0.7041 & 0.5581 & 0.3756 & 25.544 ** \\
\hline & STD & 0.1541 & 0.2341 & 0.1523 & \\
\hline
\end{tabular}

With the DEA results in hand, one now can delve more deeply into the causes of variation in the companies' technical efficiency via regression modeling. Table 8 presents the results. CRS assumes that outputs will change by the same proportion as inputs. On the other hand, VRS assumes that an additional increment of input will result in a disproportionate change in output. Therefore, VRS reflects that outputs may exhibit increasing or decreasing returns to scale. The VRS assumption is better fitting in both the traditional linear and Tobit regression models. Although the VRS variant of the traditional linear model yields the highest $\mathrm{R}^{2}$, the Tobit VRS model's fit is superior because it has the lowest values on all three evaluation criteria.

Age was not a significant part of the explanation in any of the model variants. Therefore, $\mathrm{H} 5$ could not be rejected. Likewise, six of the nine KPIs did not contribute significantly to any of the models. In the best-fitting model, though, total assets, net profit margin, the ratio of invested assets to policy liabilities, and the loss ratio (in descending order of their strength) proved to be of significant help in explaining intercompany differences in 
technical efficiency scores. Furthermore, the efficiency scores varied directly with values of the first three of these explanatory variables and inversely with values of the fourth one.

Table 8. Results from CRS and VRS Variants of Traditional and Tobit Regression Models.

\begin{tabular}{|c|c|c|c|c|c|c|c|c|c|c|c|c|}
\hline \multirow[b]{2}{*}{ Coefficient: } & \multicolumn{3}{|c|}{$\begin{array}{c}\text { Traditional Regression } \\
\text { CRS }\end{array}$} & \multicolumn{3}{|c|}{$\begin{array}{c}\text { Traditional Regression } \\
\text { VRS }\end{array}$} & \multicolumn{3}{|c|}{$\begin{array}{c}\text { Tobit Regression } \\
\text { CRS }\end{array}$} & \multicolumn{3}{|c|}{$\begin{array}{c}\text { Tobit Regression } \\
\text { VRS }\end{array}$} \\
\hline & & & $t$ & & & $t$ & & & $t$ & & & $t$ \\
\hline IAPL & 0.0089 & & 1.55 & 0.0151 & * & 2.23 & 0.0090 & & 1.62 & 0.0236 & * & 2.12 \\
\hline LR & -0.1374 & * & -2.20 & -0.1451 & & -1.93 & -0.1454 & * & -2.40 & -0.1505 & * & -1.96 \\
\hline NPM & 0.2204 & & 1.59 & 0.3033 & * & 2.17 & 0.2263 & & 1.70 & 0.3121 & * & 2.23 \\
\hline TA 1,2 & 0.0106 & & 0.60 & 0.0911 & $* *$ & 4.78 & 0.0104 & & 0.62 & 0.0925 & ** & 4.84 \\
\hline Constant & 0.1460 & & 1.01 & 0.8601 & $* *$ & 5.61 & 0.1392 & & 1.00 & 0.8582 & $* *$ & 5.55 \\
\hline $\mathrm{R}^{2}$ & 13.3700 & & & 41.8900 & $* *$ & & 20.2300 & & & 31.4800 & $* *$ & \\
\hline Log Likelihood & 23.8484 & & & 17.1913 & & & 20.4205 & & & 9.8876 & & \\
\hline $\mathrm{AIC}^{3}$ & 37.6967 & & & 24.3826 & & & 28.8411 & & & 7.7753 & & \\
\hline $\mathrm{BIC}^{4}$ & 28.5535 & & & 14.2558 & & & 17.8692 & & & 4.3768 & & \\
\hline
\end{tabular}

${ }^{*} \alpha<0.05,{ }^{* *} \alpha<0.01,{ }^{1}$ TA is natural log of total assets; ${ }^{2}$ THB tn.; ${ }^{3}$ AIC-Akaike's information criterion); ${ }^{4}$ BIC-Bayesian information criterion. The model with the lowest log-likelihood, AIC or BIC value is considered the best-fitting model (regardless of directional sign disregard the negative sign). These values are shown in bold face.

\subsection{Discussion of Results}

The $t$-test findings presented here justified the rejection of $\mathrm{H} 1, \mathrm{H} 2$, and $\mathrm{H} 3$ insofar as they pertained to the flood and post-flood periods. That is, the flood had a deleterious effect on all but one of the Thai non-life insurance companies' KPIs, an effect that persisted into the post-flood years. The ANOVA-test results, however, demonstrated that better-resourced firms operated at relatively high levels of technical efficiency across all three study periods. Instead, the entities with fewer resources were the ones whose efficiency in generating profits collapsed during the flood years and fell further still during the post-flood period. These outcomes led to the rejection of $\mathrm{H} 4$ and suggested that total assets would be an important element in accounting for the observed variation in technical efficiency scores. Regression modeling showed that indeed to be the case, warranting the rejection of H6. Given that total assets and the size of an insurance business proved to be moderately correlated, there thus also appears to be support for other researchers' conclusion that size affects profitability positively [61-65]. Additionally, the best-fitting regression agreed with the literature about the net profit margin (NPM) $[18,22,25,29,30,32,33]$ and investmentassets-to-policy-liabilities ratio (IAPL) $[18,19,22,26,34,35]$ directly affecting profitability, as well as the loss ratio's inverse influence on it $[18,19,25,26,28,30,34-36]$.

Contrary to reports in other research $[48,61]$, this study's analyses turned up no evidence of a company's age affecting any of the accounting KPIs or technical efficiency. Therefore, there was no basis to reject $\mathrm{H} 5$.

Last but not least, in every period, all of the "best practice" entities with technical efficiency scores equal to 1.0 are large non-life insurance companies whose total assets exceed USD 335 mil. This result agrees with research results showing that larger firms typically are more efficient than smaller ones [60,61].

\section{Conclusions}

The insurance industry provides important financial support to a growing economy insofar as it transfers funds from the insured to capital investment by an insurer. In this way, the development of the insurance industry can contribute to infrastructure improvement and the accumulation of productive capital. Yet, insurance pricing sometimes does not reflect risk levels or provide an adequate incentive for risk-sensitive business investment, 
particularly in low- and middle-income countries with low penetration rates but rapidly growing markets [66,67].

Thus, most Thai non-life insurance companies first need to increase their revenue (i.e., net earned premiums) in order both to boost their profits and bring down the combined ratio. Higher profits would mean larger reserves, which would lower the debt-to-equity ratio. That, in turn, would enhance insurers' liquidity and resilience, thereby strengthening their ability to continue operations when unexpected eventualities materialise. Ceteris paribus, additional revenue would improve the net profit margin (one of the best-fitting regression model's explanatory variables). It also would allow the companies to invest more in income-earning assets, thereby boosting both total assets and the IAPL ratio (another two of that model's explanatory variables).

Second, non-life insurance companies need to improve their operational efficiency. Doing so would involve managing claims better, while reducing operating expenses, thereby further improving profitability. Taken together, such measures to decrease the combined ratio (CBR) and the debt-to-equity ratio (DE) should raise the return on assets (ROA) and correspondingly increase the Thai non-life insurance industry's sustainability.

Third, to achieve greater economies of scale and operational stability, some consolidation via acquisitions and mergers within the industry may be in order. As the number of providers shrinks, though, more government regulation of the insurance industry may become necessary in order to ensure adequate competition, while preventing the formation of cartels and other oligopolistic abuses. Another measure to ensure adequate competition within the industry might be for Bangkok to encourage large (and therefore more efficient) foreign insurance companies to enter the Thai market.

Fourth, non-life insurance companies might rely more on reinsurance to achieve greater risk diversification, particularly in the face of increasing natural hazards associated with global warming. Fifth, more equity raised through the sale of shares could substitute for current high levels of debt financing, thereby reducing borrowing expenses and improving debt to equity ratios.

Sixth, the insurance companies could manage their combined expenses better, for example, by controlling commissions, brokerage fees, and operating expenses more efficiently. The novel application of DEA and Tobit regression undertaken here revealed that three of these firms operated at the peak level of technical efficiency throughout the observation periods. In-depth case studies of their management practices could identify specific, transferable, cost-cutting techniques and tools that less efficient entities might find helpful.

Seventh, the Thai non-life insurance industry might consider a more innovative product mix. Policies insuring against floods, earthquakes, other natural catastrophes or terrorism likely would attract more customers, thereby boosting written premiums. Such products might be introduced in the course of a Thai government campaign encouraging the purchase of insurance.

It is important to note that due to the 2011 historic floods in Thailand, the Thai cabinet approved The National Catastrophe Insurance Fund (NCIF) Decree on 10th January 2012 [68]. Its purpose was to help manage catastrophic risk through insurance and reinsurance. It also provided THB $50 \mathrm{bn}$. (USD $1.55 \mathrm{bn}$.) in financial assistance to the non-life insurance industry [69]. By subsidizing premiums, it made catastrophe insurance accessible to more people and businesses, while ensuring that foreign investors and local entrepreneurs would continue their operations in Thailand. The situation in confronting the country's insurance industry during the years studied was not much different from that in other countries hit by major natural disasters or catastrophes. The number of households and SMEs that have insured their property remains relatively low for a country of 70 million people. Therefore, still more effort by the Thai government to encourage and ease the purchase of flood insurance would be desirable.

From a national perspective, the need for capital to speed economic recovery in the aftermath of natural disasters is crucial. The market for nontraditional risk financing 
products, such as catastrophe bonds (CAT bonds), now account for a sizable portion of the market for property disaster retrocession. For example, in 2019, the World Bank (International Bank for Reconstruction and Development, or IBRD) issued two tranches of catastrophe-linked bonds (CAT bonds) to provide the Republic of the Philippines with three years of financial protection against earthquake losses of up to USD 75 mil. and tropical cyclone losses of up to USD 150 mil. [70]. Then, in 2020, it issued four more such bonds that will provide the Government of Mexico with financial protection of up to USD 485 mil. against losses from earthquakes and named storms for four years. These instruments have proven popular with investors. Besides international entities and national governments, they can be issued by large insurance companies. According to the statistics of insurance in developing countries, only $11 \%$ of insurance coverage applies to catastrophic damage. Consequently, governments and their citizenry will be responsible for $89 \%$ of any damage that occurs [71]. Thus, the issuance of CAT bonds could help close this insurance gap and reduce the financial risk to businesses, governments, and households.

The present study's conclusions have international relevance. Thailand's historic flood is just one example of the many kinds of catastrophe that can happen in any country. The economic and social consequences of such disasters for a country potentially are severe. Moreover, the insurance industry also may find itself in difficulty in trying to regain its pre-disaster level of efficiency, even with governmental support. Accordingly, insurance companies and related entities, such as commercial banks, state agencies, and private and public businesses need to engage continuously in planning and implementing appropriate preventative and protective measures.

This study of a natural disaster's impact on Thai non-life insurance companies' finances is the first of its kind. It has several shortcomings. To begin with, it covers just one event during a single period (2008-2014). Hence, the examination of other disasters at other times and in other national contexts may yield different results. Furthermore, the present study relied heavily on nine commonly used KPIs. Even though these KPIs are in widespread use by many scholars, it could be that employment of other indicators might produce additional or different insights. The study also included just three company characteristics. Although total assets and size (through its moderate correlation with TA) did so, other characteristics might contribute further to explaining intercompany differences in profit generating efficiency. Future research might address these limitations. In addition, one might take the best-fitting regression model's results as a starting point for in-depth interviews with the most efficient companies' executives to learn more about how they manage their total assets, net profit margin, premium revenue, losses, investments, and policy liabilities.

Future research furthermore should explore other applications of DEA to insurance company data. Here, sample size constrained that analysis and the input-output mix, though plausible, nevertheless was somewhat arbitrary. Analyses with alternative inputoutput mixes conceivably could give rise to different results.

Author Contributions: Conceptualization, K.T.; methodology, K.T.; software, K.T.; validation, K.T.; formal analysis, K.T. and R.C.R.; investigation, K.T.; resources, K.T.; data curation, K.T.; writingoriginal draft preparation, K.T. and R.C.R.; writing-review and editing, K.T. and R.C.R.; visualization, K.T. and R.C.R.; supervision, R.C.R.; project administration, K.T.; funding acquisition, K.T. All authors have read and agreed to the published version of the manuscript.

Funding: This research was funded by the Thailand Research Fund (TRF) and the Office of Higher Education Commission, Thailand, grant number MRG5980138.

Institutional Review Board Statement: The Thailand Research Fund and the Office of Higher Education Commission have approved the conceptual framework and ethics of the research. Approval number MRG5980138, dated 2 May 2016.

Informed Consent Statement: Not applicable. 
Data Availability Statement: Data is available at the website of Office of Insurance Commission, website: http:/ / www.oic.or.th/en, accessed on 8 June 2021.

Acknowledgments: We acknowledge financial support given by the fund providers; Thailand Research Fund (TF) and the Office of Higher Education Commission, Thailand.

Conflicts of Interest: The authors declare no conflict of interest. The funders had no role in the design of the study; in the collection, analyses, or interpretation of data; in the writing of the manuscript, or in the decision to publish the results.

\section{References}

1. Jonkman, S.N.; Bočkarjova, M.; Kok, M.; Bernardini, P. Integrated Hydrodynamic and Economic Modeling of Flood Damage in The Netherlands. Ecol. Econ. 2008, 66, 77-90. [CrossRef]

2. World Bank. Economic Forum, Global Risks, 8th ed.; Section 2: Testing Economic and Environmental Resilience; World Bank: Washington, DC, USA, 2013; Available online: https:/ / www.theguardian.com/business/2012/feb/14/lloyds-thailand-flooding2bn-dollars (accessed on 25 January 2012).

3. Schich, S. Insurance Companies and the Financial Crisis. Financ. Mark. Trends 2009, 2, 1-31. [CrossRef]

4. Pathak, S.; Ahmad, M.M. Flood risk reduction through insurance for SMEs in Pathumthani province, Thailand. Dev. Pract. 2018, 28, 303-310. [CrossRef]

5. Bin, O.; Kruse, J.; Landry, C. Flood Hazards, Insurance Rates, and Amenities: Evidence from the Coastal Housing Market. J. Risk Insur. 2008, 75, 63-82. Available online: http:/ / www.jstor.org/stable/25145263 (accessed on 6 June 2021). [CrossRef]

6. Botzen, W.J.W.; Bergh, J.C.J.M.V.D. Insurance Against Climate Change and Flooding in the Netherlands: Present, Future, and Comparison with Other Countries. Risk Anal. 2008, 28, 413-426. [CrossRef]

7. Botzen, W.J.W.; Van Den Bergh, J.C.J.M. Monetary Valuation of Insurance against Flood Risk under Climate Change. Int. Econ. Rev. 2012, 53, 1005-1026. [CrossRef]

8. Grmanová, E.; Strunz, H. Efficiency of insurance companies: Application of DEA and Tobit analyses. J. Int. Stud. 2017, 10, 250-263. [CrossRef]

9. Haraguchi, M.; Lall, U. Flood Risks and Impacts: A Case Study of Thailand's Floods in 2011 and Research Questions for Supply Chain Decision Making. Int. J. Disaster Risk Reduct. 2015, 14, 256-272. [CrossRef]

10. A.M. Best Co. Best Analyzes Impact of Flood Losses on Thai Insurance Industry. Insur. J. 2012. Available online: https: //www.insurancejournal.com/news/international/2012/02/10/235055.htm (accessed on 12 March 2016).

11. Global Insurance. Flood Losses Prompt Key Changes in Thai Insurance Industry; Session Best's Briefing; A.M. Best Company, Inc.: Oldwick, NJ, USA, 2012; Available online: http://www.ambest.com/press/021001thaifloodbriefing.pdf (accessed on 7 June 2017).

12. Muang Thai Insurance Annual Report. 2011. Available online: http://www.muangthaiinsurance.com/var/annualreport/MTI 2011.pdf (accessed on 5 June 2017).

13. OECD. Global Insurance Market Trend 2017. 2017. Available online: https://www.oecd.org/daf/fin/insurance/GlobalInsurance-Market-Trends-2017.pdf (accessed on 15 February 2019).

14. Trinh, T.; Nguyen, X.; Sgro, P. Determinants of non-life insurance expenditure in developed and developing countries: An empirical investigation. Appl. Econ. 2016, 48, 5639-5653. [CrossRef]

15. MarketLine.com. Life Insurance. 2018. Available online: https://store.marketline.com/search/?query=non-life+insurance\&per page $=($ accessed on 10 March 2020).

16. Office of Insurance Commission. National Catastrophe Insurance Fund Guidance. 2012. Available online: http://www.boi.go.th/ upload/content/OIC\%20(English\%20Version)_67752.pdf (accessed on 20 March 2020).

17. Haskins, E.M. A Decade of DuPont Ratio Performance. Manag. Account. Q. 2013, 14, 24-33.

18. Adams, M.; Jiang, W. Do Outside Directors Influence the Financial Performance of Risk-Trading Firms? Evidence from the United Kingdom (UK) Insurance Industry. J. Bank. Financ. 2016, 64, 36-51. [CrossRef]

19. Altuntas, M.; Rauch, J. Concentration and Financial Stability in The Property-Liability Insurance Sector: Global Evidence. J. Risk Financ. 2017, 18, 284-302. [CrossRef]

20. Elango, B. Impact of Insurers' Product Variety on Performance Across Underwriting Cycles. Manag. Decis. 2009, 47, 359-374. [CrossRef]

21. Enjolras, G.; Kast, R. Combining Participating Insurance and Financial Policies: A New Risk Management Instrument Against Natural Disasters in Agriculture. Agric. Financ. Rev. 2012, 72, 156-178. [CrossRef]

22. Kaya, E.O. Financial Performance Assessment of Non-Life Insurance Companies Traded in Borsa Istanbul via Grey Relational Analysis. Int. J. Econ. Financ. 2016, 8, 277. [CrossRef]

23. Le, H.H.; Viviani, J.L. Predicting Bank Failure: An Improvement by Implementing Machine Learning Approach on Classical Financial Ratios. Res. Int. Bus. Financ. 2017. Available online: http://www.sciencedirect.com/science/article/pii/S02755319173 01241 (accessed on 19 April 2020). [CrossRef]

24. Malafronte, I.; Porzio, C.; Starita, M.G. The Nature and Determinants of Disclosure Practices in The Insurance Industry: Evidence from European Insurers. Int. Rev. Financ. Anal. 2016, 45, 367-382. [CrossRef] 
25. Soekarno, S.; Azhari, D.A. Analysis of Financial Ratio to Distinguish Indonesia Joint Venture General Insurance Company Performance using Discriminant Analysis. Asian J. Technol. Manag. 2009, 2, 110-122.

26. Van der Heijden, H. Distributional Properties of Some Financial Ratios in Insurance. In Proceedings of the British Accounting \& Finance Association (BAFA) Annual Conference, Birmingham, UK, 12-14 April 2011.

27. Weng, T.C.; Chen, G.Z.; Chi, H.Y. Effects of Directors and Officer's Liability Insurance on Accounting Restatements. Int. Rev. Econ. Financ. 2017, 49, 437-452. [CrossRef]

28. Benali, N.; Feki, R. The Impact of Natural Disasters on Insurers' Profitability: Empirical Evidence from the Property/Casualty Insurance Industry. Res. Int. Bus. Financ. 2017. Available online: http://www.sciencedirect.com/science/article/pii/S027553191 6304834 (accessed on 24 May 2020). [CrossRef]

29. Kaminski, K.; Sterling Wetzel, T.; Guan, L. Can financial ratios detect fraudulent financial reporting? Manag. Audit. J. 2004, 19, 15-28. [CrossRef]

30. Oscar, A.J.; Sackey, F.G.; Amoah, L.; Frimpong Manso, R. The Financial Performance of Life Insurance Companies in Ghana. J. Risk Financ. 2013, 14, 286-302. [CrossRef]

31. Yu, C.P. Financial Policies on Firm Performance: The US Insurance Industry Before and After the Global Financial Crisis. Econ. Model. 2015, 51, 391-402. [CrossRef]

32. Owusu-Sekyere, F.; Kotey, A.R. Profitability of Insurance Brokerage Firms in Ghana. Acad. J. Econ. Stud. 2019, 5, 179-192.

33. Pervan, M.; Curak, M.; Marijanovic, I. Dynamic Panel Analysis of Bosnia and Herzegovina Insurance Companies' Profitability. Recent Researches in Business and Economics. 2012. Available online: http:/ / www.wseas.us/elibrary/conferences/2012/Porto/ AEBD/AEBD-24.pdf (accessed on 20 April 2019).

34. Bouriaux, S.; Russell, D.T. Loss Ratio on Insurance Equity Securities: A New Step in Insurance Securitization. J. Risk Financ. 2002, 3, 73-82. [CrossRef]

35. Lee, C.C.; Lin, C.W. Globalization, Political Institutions, Financial Liberalization, And Performance of the Insurance Industry. North Am. J. Econ. Financ. 2016, 36, 244-266. [CrossRef]

36. Mahmoud, O.H. A Multivariate Model for Predicting the Efficiency of Financial Performance for Property and Liability Egyptian Insurance Companies. In Applying Multivariate Statistical Models; CAS Discussion Paper Program: Québec City, QC, Canada, 2008; pp. 53-78.

37. Almajali, A.Y.; Alamro, S.A.; Al-Soub, Y.Z. Factors Affecting the Financial Performance of Jordanian Insurance Companies Listed at Amman Stock Exchange. J. Manag. Res. 2012, 4, 266-289. [CrossRef]

38. Cowling, M.; Bates, P.; Jagger, N.; Murray, G. Study of the Impact of the Enterprise Investment Scheme (EIS) and Venture Capital Trusts (VCTS) on Company Performance. In HM Revenue \& Customs Research Report 44; Institute for Employment Studies: Brighton, UK, 2008.

39. Lumpkin, G.; Dess, G.G. Linking two dimensions of entrepreneurial orientation to firm performance: The moderating role of environment and industry life cycle. J. Bus. Ventur. 2001, 16, 429-451. [CrossRef]

40. Malik, H. Determinants of Insurance Companies Profitability: An analysis of Insurance Sector of Pakistan. Acad. Res. Int. J. 2011, 1, 315-321.

41. Mehari, D.; Aemiro, T. Firm Specific Factors that Determine Insurance Companies' Performance in Ethiopia. Eur. Sci. J. 2013, 9 , 245-255.

42. Vijayakumar, D.A.; Kadirvelu, S. Determinants of Profitability in Indian Public Sector Petroleum Industries. Manag. Labour Stud. 2003, 28, 170-182. [CrossRef]

43. Vijayakumar, D.; Kadirvelu, S. Determinants of profitability: The case of Indian Public Sector Power Industries. Manag. Account. 2004, 39, 118-124.

44. Liargovas, P.G.; Skandalis, K.S. Motives and Marketing Strategies of Greek Companies Exporting to South-East European Markets. South-East. Eur. J. Econ. 2008, 2, 227-244.

45. Browne, M.J.; Carson, J.M.; Hoyt, R.E. Dynamic Financial Models of Life Insurers. N. Am. Actuar. J. 2001, 5, 11-26. [CrossRef]

46. Charumathi, B. On the Determinants of Profitability of Indian Life Insurers-An Empirical Study. In Proceedings of the World Congress on Engineering, London, UK, 4-6 July 2012.

47. Chen, R.; Wong, K. The Determinants of Financial Health of Asian Insurance Companies. J. Risk Insur. 2004, 71, 469-499. [CrossRef]

48. Joo, B.A. Analysis of Financial Stability of Indian Non-Life Insurance Companies. Asian J. Financ. Account. 2013, 5, 306-319. [CrossRef]

49. Cummins, J.D.; Harrington, S.E.; Klein, R. Insolvency Experience, Risk Based Capital and Prompt Corrective Action in PropertyLiability insurance. J. Bank. Financ. 1995, 19, 511-527. [CrossRef]

50. Majumdar, S.K. The Impact of Size and Age on Firm-Level Performance: Some Evidence from India. Rev. Ind. Organ. 1997, 12, 231-241. [CrossRef]

51. Yao, S.; Han, Z.; Feng, G. On technical efficiency of China's insurance industry after WTO accession. China Econ. Rev. 2007, 18, 66-86. [CrossRef]

52. Borges, M.R.; Nektarios, M.; Barros, C.P. Analysing the efficiency of the Greek life insurance industry. Eur. Res. Stud. 2008, 11, 35-52.

53. Barros, C.P.; Nektarios, M.; Assaf, A. Efficiency in the Greek insurance industry. Eur. J. Oper. Res. 2010, 205, 431-436. [CrossRef] 
54. Farrell, M.J. The measurement of productive efficiency. J. R. Stat. Soc. 1957, 3, 253-290. [CrossRef]

55. Charnes, A.; Cooper, W.; Rhodes, E. Measuring the efficiency of decision-making units. Eur. J. Oper. Res. 1978, 6, 429-444. [CrossRef]

56. McDonald, J. Using least squares and tobit in second stage DEA efficiency analyses. Eur. J. Oper. Res. 2009, 197, 792-798. [CrossRef]

57. Akaike, H. Information theory and an extension of the maximum likelihood principle. In Second International Symposium on Information Theory; Kotz, S., Johnson, N.L., Eds.; Academia Kiado: Budapest, Hungary, 1973; pp. 267-281.

58. Schwarz, G. Estimating the Dimension of a Model. Ann. Stat. 1978, 6, 461-464. [CrossRef]

59. Bos, J.W.; Kolari, J. Large Bank Efficiency in Europe and the United States: Are There Economics Motivations for Geographic Expansion in Financial Service? J. Bus. 2005, 78, 1555. [CrossRef]

60. Abidin, Z. Financial and Production Performances of Domestic and Foreign Banks in Indonesia: Pre and Post Financial Crisis. Manaj. Usahaw. Indones. 2006, 6, 3-9.

61. Andoh, C.; Yamoah, S.A. Reinsurance and Financial Performance of Non-life Insurance Companies in Ghana. Manag. Labour Stud. 2021, 46, 161-174. [CrossRef]

62. Doğan, M. Relations between the profitability and capital structure of insurance companies: An analysis over the Turkish capital market. J. Account. Financ. 2013, 57, 121-136.

63. Burca, A.M.; Batrînca, G. The determinants of financial performance in the Romanian insurance market. Int. J. Acad. Res. Account. Financ. Manag. Sci. 2014, 4, 299-308. [CrossRef]

64. Ćurak, M.; Pepur, S.; Poposki, K. Firm and economic factors and performance: Croatian composite insurers. Bus. Rev. Camb. 2011, 19, 136-142.

65. Shiu, Y. Determinants of United Kingdom general insurance company performance. Br. Actuar. J. 2004, 10, 1079-1110. [CrossRef]

66. UNISDR. 2011 Global Assessment Report on Disaster Risk Reduction: Revealing Risk, Redefining Development; Information Press: Oxford, UK, 2011.

67. UNISDR. 2013 Global Assessment Report on Disaster Risk Reduction: Revealing Risk, Redefining Development; Information Press: Oxford, UK, 2013.

68. ARTEMIS. 2012. Available online: https://www.artemis.bm/news/thailand-to-establish-catastrophe-insurance-fund/ (accessed on 5 June 2021).

69. Fiscal Policy Office. Executive Summary and Research Disclosures. 2011. Available online: http:/ /www.fpo.go.th/eresearch/ getattachment/3fba49ae-bbb9-4b83-b75b-d7583b44dec5/9150.aspx (accessed on 5 June 2021).

70. The World Bank. World Bank Catastrophe Bond Transaction Insures the Republic of Philippines against Natural Disaster-Related Losses Up to US\$225 million. Available online: https://www.worldbank.org/en/news/press-release/2019/11/25/worldbank-catastrophe-bond-transaction-insures-the-republic-of-philippines-against-natural-disaster-related-losses-up-to-usd225 -million (accessed on 7 June 2021).

71. ThaiBMA. Cat Bond. 2019. Available online: https://www.thaibma.or.th/EN/Investors/Individual/Blog/2019/13082019.aspx (accessed on 8 June 2021). 